\title{
CONTENT OF HUMAN RIGHT TO FAVORABLE ENVIRONMENT IN GENERAL INTERNATIONAL LAW
}

\section{Getman A. P., Shchokin Y. V., Hetman Y. A.}

\section{INTRODUCTION}

The concept of international human environmental rights has been maturating gradually, as international cooperation practices of states in the field of conservation and rational use of natural resources accumulated and, in fact, as the theory and practice of international human rights protection advanced. The natural result of a gradual development of international legal commitments of states in the environmental sphere was formation of the right to a favorable environment as one of the fundamental international human environmental rights ${ }^{1}$.

The modern doctrine of international law indicates that a general international consensus has been achieved only in regard to four kinds of environmental rights to: a) favorable environment; b) access to environmental information; c) public participation in environmental decisionmaking; and d) access to environmental justice ${ }^{2}$. These rights are regarded as a generally recognized international legal framework for a subsequent broad-scale development of the entirety of international human environmental rights. Thus, apart from the above-mentioned rights, the following rights are also identified: to health; to access to fresh water; property right to natural resources, etc ${ }^{3}$.

The right to a favorable environment is a fundamental subjective human right. As A. M. Solntsev notes, its place in the system of human

${ }^{1}$ This, in particular, is emphasized by T.R. Korotkiy. He points out that the first traditional domains of regulating international environmental rights were relations pertaining to environmental protection, as well as those pertaining to rational nature management. And only later on, the scientist continues, the said domains were supplemented by environmental safety relations and those securing human environmental rights. (T.R. Korotkiy, Ecologization of international law in the light of environmental human rights, p. 134, at: http://archive.nbuv.gov.ua/portal/Soc_Gum /App/2012_44/ Korotkiy.pdf) [in Russian].

${ }^{2}$ Solntsev A.M., Protection of Environmental Human Rights, 2015, p. 25 [in Russian]; N.B. Mushak, Conceptual approaches to classification of human rights under globalization processes, Chasopys Kyivskoho universytetu prava, 2011, No 2, p. 300) [in Ukrainian].

${ }^{3}$ Mushak N.B., supra. 
rights is determined by the fact that providing basic life support it acts as inborn, intrinsic human quality ${ }^{4}$. In other words, this right is so valuable that it tops the hierarchy of the presently shaping international human environmental rights as well as the hierarchy of long-established in international law and national legal systems civil, political, social, economic, and cultural rights i.e. human rights of first and second generations.

This right corresponds to the human right of the Ukrainian national law to an environment that is safe for life and health, directly provided for in Art. 50 of the Constitution of Ukraine. Experts point out that the formulation of the right is so judgmental that its profound meaning leads to paradoxical results. On the one hand, an axiological sense of the norm is so significant that it claims to have the status of "an international legal environmental imperative" . While on the other hand, the latitude of thought about the norm content, the ambiguity of interpretation of every single word recorded therein diminishes the practical value of the norm, turning it into a slogan. It is well-known that in a modern democratic state governed by the rule of law the legal provisions for human rights should not be too much itemized so as courts could have a certain degree of discretion in interpreting a specific human right depending on the specificity of every examined case. At the same time, it is the positive law that should indicate the lines of interpretation and even its limits in a particular context.

The lines and limits of interpreting the human right to an environment that is safe for life and health are determined in two legal domains national-legal and international-legal. They are intermingled, interconnected and affect each other. The Ukrainian legislators who accepted voluntarily the concept of the primacy of international law thereby consented to priority application of international-legal standards of the law under consideration. Yet, these standards are still insufficiently explored in the Ukrainian juridical science.

The objective of the present paper is to determine the content of the human right to a favorable environment and sources of its consolidation in the modern international law.

\footnotetext{
${ }_{5}^{4}$ Solntsev A.M., supra at pp. 25, 26.

${ }^{5}$ Getman A.P. \& Kostytskyi V.V., Human environmental rights in the national and international legal doctrine, Problems of Legality, 2013, Issue 124, p. 78 [in Ukrainian].
} 


\section{Recognition of the idea of protection of international human environmental rights}

At the beginning of the development of international human environmental rights, a number of leading experts expressed their doubts about the viability of separating these rights, pointing out, in particular, a possible blurring and, consequently, decline in legal influence of the acknowledged human rights, well enshrined in general and regional international law and tried by extensive practice of their application. The formulation of international environmental rights, brought up for discussion, was criticized for non-specificity, obscurity, and lack of proper level of specialization ${ }^{6}$.

This, in particular, was mentioned by D. Shelton in 1991. She agreed with the idea that both the areas of international law - human rights and environmental protection - ultimately strive to attain the highest quality of a sustainable human life within the framework of the existing global ecosystem ${ }^{7}$. However she also stressed their fundamental innate contradictions, emergent at the primary level of goal setting. The researcher wrote that the essential interest of the human rights law consists in protection of individuals living in a given society, while the goal of environmental law is sustaining life around the world by correlating today's needs and possibilities with the future needs and possibilities ${ }^{8}$.

D. Shelton indicated a close connection between environmental rights and the political consensus reached in intergovernmental relations which affects directly the efficiency of the work on compliance with international procedures $^{9}$. As an example of the negative consequences of inefficient implementation of international human rights-based instruments due to a lack of political consensus among the leading states in the international arena, the researcher instances the fate of the 1966 International Covenant on Economic, Social and Cultural Rights. The USA refused to recognize and apply it, having declared the very idea of those human rights to be "a myth" ". Similarly, she pointed out the solidarity nature of environmental

${ }^{6}$ Lewis B., Environment Rights or A Right to the Environment? Exploring the Nexus between Human Rights and Environment Protection, Macquarie Journal of International and Comparative Environment Law, 2012, Vol. 8 (1), pp. 44-45.

Shelton D., Human Rights, Environmental Rights and the Right to Environment, Stanford Journal of International Law, 1991, Vol. 28, p. 111.

${ }^{8} \mathrm{Id}$.

${ }^{9}$ Id., at pp. 117, 118.

${ }^{10}$ Id., at p. 121. 
rights which rarely refer to a single individual. Due to a dynamic and changeable character of the nature, its deterioration, the environmental rights, as a rule, are applied most widely ${ }^{11}$.

Another well-known environmentalist lawyer A. Boyle confessed that in 1996 he shared the skepticism expressed by numerous Western experts with regard to an idea of enshrining in law the human right to a favorable environment. He writes that it looked like an attempt to turn an essentially political issue into a legal one, which could help seize power from democratically accountable politicians and transfer it to courts or treaty bodies. The Western governments were sure that this UN idea was stillborn $^{12}$. As years went by, the scientist stresses, he did not lose his skepticism, yet he had to correct his stand substantially, mostly because he realized the significance of that right for the countries where environmental concerns are more critical and complicated than in Western Europe ${ }^{13}$.

L. Horn agrees that the human right to a healthy environment is underpinned by the need for survival. At the same time, however, she focuses on the reasoning typical of the representatives of multiple international non-governmental environmental organizations and movements which follow a tradition of opposing the "objective" needs of a modern urbanized society to the "objective" needs of the fauna in particular, and the wildlife in general. She argues that this approach is justified, since preservation of the environment is necessary for improving the quality of human life. The problem aspect of the approach lies in emphasizing the supremacy of human beings over the nature. It supports a utilitarian theory and an assumption that the nature serves largely the purpose of humans' well-being ${ }^{14}$.

Despite numerous objections, the need for finding a commonly acceptable solution to the problem of substantiating international human environmental rights and providing each of them with their own unique content was obvious. At the highest international level this was best expressed by Vice-President of the International Court of Justice

${ }^{11}$ Id., at p. 124.

12 Boyle A., Human Rights and the Environment: Where Next? European Journal of International Law, 2012, Vol. 23, P. 627.

${ }^{13}$ Boyle A., supra at p. 627.

${ }^{14}$ Horn L., The Implications of the Concept of Common Concern of a Human Kind on a Human Right to a Healthy Environment, Macquarie Journal of International and Comparative Environment Law, 2004, Vol. 1, p. 239. 
C.G. Weeramantry in his dissenting opinion about the judgment in the case of Gabčíkovo (Hungary/Slovakia, 1997). The Justice declared that environmental protection is a vital part of the modern human rights doctrine, since it is a sine qua non for numerous human rights, such as the right to health, and the right to life itself. It is hardly necessary to prove that damage caused to the natural environment may diminish and undermine all the human rights specified in the Universal Declaration of Human Rights and other human rights instruments ${ }^{15}$.

Later on quite a number of scientists spoke in support of separation of international human environmental rights. At present, systematization of the relevant argumentation is underway. For instance, F.K. Nkusi puts forward the following arguments: a) a connection between human rights and impact of the environment on the life, health, privacy, and property of physical persons is closer than links with other states and the external environment as a whole; b) separation of human rights can give an impetus to provision of higher standards of environment quality based on the states' commitments to take steps aimed at controlling pollutions harmful to people's health and private life; c) the existence of international human environmental rights helps promote the rule of law in the sphere of ecology, since governments become directly responsible for their own faults in implementation of these rights, and for control over pollution, caused by corporations as well; d) respect for human rights encourages public participation in making decisions on environmental issues, facilitates access to the relevant information and justice; e) human rights allow differentiating more clearly between various components of public interests in the sphere of environmental protection; f) human rights are associated with climate change ${ }^{16}$.

S. Glazebrook puts forward the main arguments made by the opponents of separation of international human environmental rights, entering into a debate with them. In particular, she agrees with their opinion that introduction of new rules may affect negatively the established system of human rights, devaluating them. At the same time, she notes that reluctance to adapt the existing documents or extend the rights in accordance with changing circumstances may produce the same

\footnotetext{
${ }^{15}$ Gabčíkovo-Nagymaros Project (Hungary/Slovakia), Judgment of 25 September 1997, Separate Opinion of Vice-President Weeramantry, I.C.J. Reports, 1997, pp. 91-92.

${ }^{16}$ Nkusi F.K., A Right to Healthy Environment: The Nexus between Environmental Protection and Human Rights, East African Journal of Science and Technology, 2015, Vol. 5, Issue 1, p. 222.
} 
effect. The scientist believes that new rights should not be added if they are trivial, but the right to a quality environment can be regarded as one of the keystones determining other rights ${ }^{17}$. Recognizing the difficulty of coordination of the new right content with that of the existing rights, she points out that even if the new right were not articulated yet, this does not mean it is nonexistent ${ }^{18}$. She emphasizes that any environmental right will include in itself the right to biodiversity and responsibility for protection of biodiversity and ecosystems ${ }^{19}$. According to S. Glazebrook, individualization of the right to the environment does not contradict its collective nature. Individual and collective interests always coincide in the right protection, individualization merely enhancing $\mathrm{it}^{20}$.

B. Weston and D. Bollier indicate that, firstly, human rights provide the level of responsibility that goes beyond the scope of other legal obligations; they represent physical values of "the highest" legal and moral order, and therefore, infringement thereof entails stronger moral condemnation than other violations ${ }^{21}$. Secondly, according to the scientists, this is exactly what promotes the influence on the authorities, which is of great importance, especially when persons affected as a result of large-scale environmental catastrophes try to hold liable big economic and political forces. Thirdly, human rights protection opens up direct access to international human rights machinery. In the fourth place, human rights having greater moral strength than usual legal obligations lay the legal basis for the respective political and public activity ${ }^{22}$. And in the fifth place, as B. Weston and D. Bollier state, human rights stimulate formation of initiatives inside and outside the civil society, meant to contribute to meeting primary human needs ${ }^{23}$.

In the view of some scientists, individualization of environmental rights does not result in strengthening of the utilitarian theory, set against 'green' or 'deep ecology' philosophic mindset, widespread among international environmental human rights organizations and movements.

17 Glazebrook S., Human Rights and the Environment. Victoria University of Wellington Law Review, 2009, Vol. 40, p. 317.

${ }^{18}$ Glazebrook S., supra at p. 317.

${ }^{19}$ Id., at p. 318.

${ }^{20}$ Id., at pp. $319-320$.

${ }^{21}$ Weston B.H. \& Bollier D., Regenerating the Human Right to a Clean and Healthy Environment in the Commons Renaissance. Essay, Version 1.0., September 2011, P. 74, at: http://commonslawproject.org/sites/default/files/Regenerating\%20Essay\%2C\%20Part\%20I.pdf.

${ }^{22}$ Id., at p. 75.

${ }^{23}$ Id., at p. 76. 
The theorists of deep ecology highlight crucial distinctions between individual environmental rights and objective needs of non-human life. They stress that environmental rights, like all human rights, cannot be anthropocentric, since human needs do not match the needs of the wildlife, more often contradicting them. The legal quintessence of this philosophy became the theory of Mother Nature's rights, embodied in the Universal Declaration of the Rights of Mother Earth, adopted at the Conference on Global Warming and Rights of Mother Earth, held in Cochabamba (Bolivia) on 22 April 2010, which united in a unique way state agents and civil society representatives from over 100 nations. The Declaration is apparently of non-anthropocentric nature. This is clearly indicated, in particular, in para. 5 Art. 1 declaring the right of Mother Earth and all life forms to all the inherent rights regardless of usefulness for human beings $^{24}$.

However modern advocates of environmental rights individualization not only look differently upon deep ecology philosophers' concerns; moreover, they believe that it is individualization that will reduce these controversies. This, for example, is mentioned by B. Lewis. She emphasizes an idea that inclusion of the right to a healthy environment into international human rights treaties will not only make it equal to other human rights, but will also help balance the general environmental needs with people's own needs ${ }^{25}$. The same position was taken up by the above-mentioned B. Weston and D. Bollier. However, they made a distinction between traditional anthropocentrism and that of the intergenerational rights approach. The latter is practically non-egoistic and much less human-oriented than the anthropocentrism of the traditional human rights approach that focuses largely on persons unaware of their potential distant future ${ }^{26}$.

In fact, a new concept of the common concerns of mankind that replaced the mankind common heritage concept was meant to overcome this discrepancy and blur out the said contradictions. The former concept, as distinct from the latter, according to L. Horn, is more advantageous for characterizing the climate and biological diversity as common concerns components. But the key legal difference between the 'common concerns' and 'common heritage' consists in that the common concerns penetrate the

${ }^{24}$ Universal Declaration of the Rights of Mother Earth, 28 April 2010 (Cochabamba, Bolivia), at: http://www.rightsofmotherearth.com/универсальная-декларация-прав-материземли [in Russian].

${ }^{25}$ Lewis B., supra at p. 41.

${ }^{26}$ Weston B.H. \& D. Bollier, supra at p. 42. 
domain of the states' exercising sovereign powers, and link them with global interests ${ }^{27}$. In other words, common heritage of mankind law is limited mainly to international territories ${ }^{28}$, while the emerging law of common concerns of mankind is international in the sense that it does not recognize any state borders.

\section{Stages of forming the content of legal standards of the human right to a favorable environment in general international law}

The human right to a favorable environment was being formed as international environmental law itself was evolving. The doctrinal periodization of the latter, as a rule, is related to a number of universal international conferences, which marked the adoption of international legal and political documents that accumulated sometimes challenging consensus on pressing aspects of environmental protection.

The first stage - 1839-1972. Its start dates back to 2 August 1839 - the date of signing a bilateral Convention on dredging oysters and fishing near the shores of Great Britain and France ${ }^{29}$. The end of it was completion of the preparatory work for 1972 UN Conference on the Human Environment held in Stockholm.

The second period is "the Stockholm era". The timeframe of the period includes the results of the work of the UN Stockholm Conference on the Human Environment held in 1972 and preparation for the United Nations Conference on Environment and Development (UNCED), Rio de Janeiro, 1992. During that period, the basic normative framework for this area of law was formed - more than 1,100 international instruments were adopted that were either completely devoted to environmental issues or contained important provisions relating to the environment ${ }^{30}$.

The third period - "the Rio de Janeiro era", which lasted from 1992 to 2012, that is from the time of adoption of the Declaration on Environment and Development at the UN Conference on Environment and Development of June 3-14 1992, and to the next conference held in Rio de Janeiro (Rio+20).

${ }^{27}$ Horn L., supra at p. 244.

28 Malanczuk P., Akehurst's Modern Introduction to International Law, 1997, p. 207-208; M. N. Shaw, International Law, 2008, pp. 533-534.

${ }^{29}$ M.N. Kopylov, S.M. Kopylov \& V.A. Mishlanov, International Environmental Law is 175, Moscow Journal of International Law, 2014, № 1 (93), p. 104 [in Russian].

${ }^{30}$ Weiss E.B., The Evolution of International Environmental Law, Japanese Yearbook of International Law, 2011, p. 6. 
The fourth period - a modern one - is connected with a new wave of international law "ecologization" and actualization of fighting for preservation of climate and biological diversity ${ }^{31}$.

\subsection{The stage of primary "ecologization" of generally recognized human rights and freedoms (1839-1972)}

As E. B. Weiss puts it, the period before 1972 was the time of "early glimmers" in the development of international environmental law. Its principles and standards were poorly developed, and, on the one hand, convictions that states had complete sovereignty over their territories and natural resources were dominating; on the other hand, almost religious "respect for the nature" was universal ${ }^{32}$.

In that context, the "glimmers" of the human right to a favorable environment was hardly perceivable. In actual fact, it is only by the end of the period - after World War II and foundation of the UNO - that inalienable civil, socio-economic, and cultural human rights were enshrined in the universal and regional international law, following decades of work aimed at general legal protection of human environmental needs. This refers to the right to life (Art. 3 of the 1948 Universal Declaration of Human Rights, Art. 6 of the 1966 International Covenant on Civil and Political Rights); the right to the living standards, including food, housing, healthcare, and social services, which are necessary to support the health and welfare (para. 1 Art. 25 Universal Declaration of Human Rights (1948), Art. 11 of the International Covenant on Economic, Social, and Cultural Rights (1966)); the right to the highest level of physical and mental health (Art. 12 of the International Covenant on Economic, Social, and Cultural Rights (1966)).

We would like to stress that during that period the forming practice of interpreting the legal standards was but most general and very close to their common meaning and original spirit. It was quite far from the environmental agenda. Even within the scope of applying such an advanced regional human rights instrument as the Convention for the Protection of Human Rights and Fundamental Freedoms of 1950, the first "environmental" cases appeared long after the period of forming international environmental law was over i.e. after 1972.

\footnotetext{
${ }^{31}$ Kopylov M.N., Kopylov S.M. \& Mishlanov V.A., supra at pp. 113-114.

${ }^{32}$ Weiss E.B., supra at pp. 2-4.
} 
Thus, the first claims submitted for consideration to the Commission on Human Rights in the 1960s-1970s, addressing various environmental aspects (Dr. S. v. the Federal Republic of Germany, Application No. 715/60, Decision of inadmissibility of 5 August 1969; X. and Y. v. the Federal Republic of Germany, Application No.7407/76, Decision of inadmissibility of 13 May 1976), were dismissed as ratione materiae with the Convention. The first environmental cases on which the Commission agreed to pass judgment despit ratione materiae date from the 1980s (Arrondelle v. the United Kingdom, Application No. 7889/77, Decision of 15 July 1980; G. and Y. v. Norway, Application No. 9415/81, Decision of 3 October 1983, and other cases). In the same period the first 'environmentally-related' decisions of the European Court of Human Rights (ECHR) appear (Sporrong and Lönnroth v. Sweden, Judgment of 23 September 1982; Gillow v. the United Kingdom, Judgment of 23 October 1986$)^{33}$.

It should be mentioned, though, that each of the above-said decisions of the Commission and the Court was merely the result of their own longlasting procedures, preceded by inner-state trial procedures on the relevant cases. For applicants, a connection between environmental protection problems and conventional rights was apparent initially. Yet, even now, ECHR, when making judgment ratione materiae and touching, to a degree, upon environmental problems, underlines that the Convention standards are not intended for that. Its standpoint stated in para. 52 of the court decision on the case of Kyrtatos v. Greece, (2003) is well-known: neither Article 8, nor any other article of the Convention was purposefully meant to provide a general environmental protection as such ${ }^{34}$.

However the bulk of the ECHR practice, more or less related to protection of the human right to a favorable environment, formed according to 'non-environmental' articles, has reached a critical level which makes it possible to gain a clear impression of what the content of this right should be. At the same time, from the ideological perspective, the practice of ECHR is remarkable because it has demonstrated conclusively both the closest connection between conventional and environmental human rights and the necessity for environmental rights individualization.

${ }^{33}$ García D.I. San José, Environment Protection and the European Convention on Human Rights, Council of Europe Publishing, 2005, pp. 7-11; S. Kravchenko \& J.E. Bonine, Interpretation of Human Rights for the Environment in the European Court of Human Rights, Global Business \& Development Law Journal, 2012, Vol. 25, p. 245-287.

${ }^{34}$ Case of Kyrtatos v. Greece (Application No. 41666/98), Judgment, 22 May 2003. 


\subsection{The stage of forming a common UN political and expert position on the expediency of individualizing the human right to a favorable environment (1972-1992)}

In the period of 1972-1992, the human right to a favorable environment was individualized in a number of international political documents. It is considered that it was first declared to be an individual human right in the Declaration of the UN Conference on the Human Environment, adopted on June 161972 in Stockholm (Stockholm Declaration, 1972). Pursuant to Principle 1 of the Declaration, "Man has the fundamental right to freedom, equality and adequate conditions of life, in an environment of a quality that permits a life of dignity and wellbeing, and he bears a solemn responsibility to protect and improve the environment for present and future generations".

It should be noted that it is the only principle in the document which its drafters put on record as an individual human right and formulated as a self-executing norm i.e. as a rule of law that can be applied directly by the interested entities. Another human-friendly norm is recorded in Principle 4, but it has the form of an individual obligation, rather than a right: "Man has a special responsibility to safeguard and wisely manage the heritage of wildlife and its habitat, which are now gravely imperiled by a combination of adverse factors." That is why in planning of economic development a prominent place should be given to preservation of nature, including wildlife.

On 28 October 1982, the General Assembly adopted Resolution $37 / 7$ titled the World Charter for Nature. The document links directly human life with a favorable environment. Thus, the preamble to the Charter states that mankind ensures "the supply of energy and nutrients"; "living in harmony with nature gives man the best opportunities for the development of his creativity, and for rest and recreation". Paragraph 9 of the Charter indicates the need for a rational and planned use of nature: "The allocation of areas of the earth to various uses shall be planned, and due account shall be taken of the physical constraints, the biological productivity and diversity and the natural beauty of the areas concerned." Paragraph 10 lays out the rules, according to which natural resources should be "used with a restraint", namely: "a) living resources shall not be utilized in excess of their natural capacity for regeneration; b) the productivity of soils shall be maintained or enhanced through measures which safeguard their long-term fertility and the process of organic decomposition, and prevent erosion and all other forms of degradation; 
c) resources, including water, which are not consumed as they are used shall be reused or recycled; d) non-renewable resources which are consumed as they are used shall be exploited with restraint, taking into account their abundance, the rational possibilities of converting them for consumption, and the compatibility of their exploitation with the functioning of natural systems".

A special attention should be paid to paragraph 23 of the World Charter for Nature. It is the only paragraph that directly applies to man: "All persons, in accordance with their national legislation, shall have the opportunity to participate, individually or with others, in the formulation of decisions of direct concern to their environment, and shall have access to means of redress when their environment has suffered damage or degradation".

In 1983, the General Assembly of the UNO established the World Commission on Environment and Development (WCED), chaired by a famous Norwegian political figure and diplomat Mrs. Gro Harlem Brundtland. In 1987, the Commission published a report under the title of "Our Common Future"35 (hereafter - Brundtland Report), the report that introduced the idea of sustainable development which laid an ideological foundation for the modern UN activity. Thus, para. 4 subsection 1 Chapter 2 of Brundtland Report holds: "The satisfaction of human needs and aspirations in the major objective of development. The essential needs of vast numbers of people in developing countries for food, clothing, shelter, jobs - are not being met, and beyond their basic needs these people have legitimate aspirations for an improved quality of life. A world in which poverty and inequity are endemic will always be prone to ecological and other crises. Sustainable development requires meeting the basic needs of all and extending to all the opportunity to satisfy their aspirations for a better life" ${ }^{, 36}$.

On the whole, Brundtland Report appeals to states. Nevertheless, a number of its provisions determined the prospects for developing individual human rights. They are of a clearly pronounced environmental nature. For example, para. 80 Chapter 12, concerning the means for legal regulation of sustainable development, stipulates that "human laws must

${ }^{35}$ Report to the UN General Assembly of the World Commission on Environment and Development "Our Common Future" of 4 August 1987 (Doc. A/42/427, Russian), 411 p., at: http://www.un.org/ru/ga/pdf/brundtland.pdf [in Russian].

${ }^{36} \mathrm{Id}$. 
be reformulated to keep human activities in harmony with the unchanging and universal laws of nature" ${ }^{, 37}$. Paragraph 82 of the same chapter states that "recognition by states of their responsibility to ensure an adequate environment for present as well as future generations is an important step towards sustainable development. However, progress will also be facilitated by recognition of, for example, the right of individuals to know and have access to current information on the state of the environment and natural resources, the right to be consulted and to participate in decision making on activities likely to have a significant effect on the environment, and the right to legal remedies and redress for those whose health or environment has been or may be seriously affected" 38 . It stands to reason that the 'rights of individuals' refer to the rights of every particular person, not the rights of the few.

Paragraph 1 of the Summary of the Proposed Legal Principles for Environmental Protection and Sustainable Development Adopted by the WCED Experts Group on Environmental Law (Annex 1 to Brundtland Report) defines the fundamental human right as follows: "All human beings have the fundamental right to an environment adequate for their health and well being" 39 .

\subsection{The stage of forming common political obligations to ensure the human right to a favorable environment under the UN aegis (1992-2012)}

The first universal political document that embodied the ideas of Brundtland Report was the Declaration on Environment and Development adopted by the UN Conference on Environment and Development held from 3 to 14 June 1992 in Rio de Janeiro. The Rio Conference of 1992 elaborated the principles of international environmental law development, determined its goals and main ways for the states to cooperate in that field. The Conference adopted the Rio Declaration on Environment and Development, United Nations Framework Convention on Climate Change, Convention on Biological Diversity, and Agenda 21.

Discussing establishment of connections, E.B. Weiss points out entwinement of the forming rules of international environmental law with other international law areas, namely: international economic law, law of

\footnotetext{
${ }^{37}$ Id.

${ }^{38}$ Id.

${ }^{39}$ Id.
} 
international security, law of international organizations, and, of course, international human rights law. It should be emphasized that, in the view of the researcher, connection between international environmental law and international protection of human rights manifested itself, in the first place, in individualization of the human right to a clean, favorable and healthy environment ${ }^{40}$.

Without doubt, the position of E.B. Weiss should be fully supported. But at the same time, it stands to mention that the documents adopted at the Rio Conference in 1992 basically apply to states. For example, the principles laid out in the Rio Declaration on Environment and Development address member states and are a sort of agenda for consolidation of their mutual efforts in the environmental sphere. Human rights in this agenda are formulated by Principle 1, although in collective rather than individual capacity. They can be regarded as a priority goal of the Declaration and not as a specific self-executable obligation: "Human beings are at the centre of concerns for sustainable development. They are entitled to a healthy and productive life in harmony with nature".

Many experts have noticed the equivocation of the legal rule formulated in Principle 1. For instance, M.L. Schwartz, making comments on this situation, pays attention to the fact that the Rio Declaration does not explicitly specify 'the right' of an individual to life in a healthy environment as it was done twenty years before by the Stockholm Declaration. The Rio Declaration states that individuals 'are entitled' to a health life. However, the researcher notes, it is not clear if the second term has a narrower meaning than the first one ${ }^{41}$. As S.P. Marks puts it, the wording of Principle 1 does not indicate expressly that there exists a human right to a clean and ecologically balanced environment, but it nails down the problem in human rights parlance ${ }^{42}$. L. Horn is more categorical saying that Principle 1 does not denote directly 'human entitlements' as 'a human right', which can definitely be regarded as a failure of the Rio Declaration and regress in this right evolution ${ }^{43}$.

Neither the UN Framework Convention on Climate Change nor the Convention on Biological Diversity of 1992 addresses human rights. The

\footnotetext{
${ }^{40}$ Weiss E.B., supra at p. 15.

${ }^{41}$ Schwartz M.L., International Legal Protection for Victims of Environmental Abuse. Yale Journal of International Law, 1993, Vol. 18, Issue 1, Art. 15, p. 374.

${ }^{42}$ Marks S.P., Emerging Human Rights: A New Generation for the 1980s? Rutgers Law Review, 1981, Vol. 33, p. 443.

${ }^{43}$ Horn L., supra at p. 235.
} 
Agenda 21 is a full-fledged agenda for actions which the 1992 Rio Conference participant states deem necessary to take for effective environmental protection. It is a set of political commitments of the states rather than legal ones, as is mentioned in para. 1.3 of the document: "Agenda 21 addresses the pressing problems of today and also aims at preparing the world for the challenges of the next century. It reflects a global consensus and political commitment at the highest level on development and environment cooperation" "44. The Agenda 21 does not touch upon environmental human rights issues either, which by no means indicates a lack of interest in it.

On 31 August 1989, the United Nations Sub-Commission on the Prevention of Discrimination and Protection of Minorities in its Decision 1989/108 suggested that Mrs F.Z. Ksentini prepare a brief note on methods for researching environmental problems and their interrelation with human rights. None of the UN bodies has ever dealt with these issues. After a series of discussions of the work done by F.Z. Ksentini as Special Rapporteur on the subject, her powers were enhanced considerably. On 6 July 1994, she submitted to the UN Economic and Social Council, the Commission on Human Rights and the SubCommission on the Prevention of Discrimination and Protection of Minorities her Final Report titled "Human Rights and the Environment", known as "Ksentini Report"

The Report presents environmental aspects of realization of such fundamental human rights and freedoms as the right to life (para. 172-175); the right to health (para. 176-187); the right to food (para. 188-191); the right to occupational health (para. 192-194); the right to housing (para. 195-202); the right to information (para. 203-216); freedom of association (para. 224-225); cultural rights (para. 226-234). The Special Rapporteur pointed out an indispensible link between effective environmental protection and effective realization of these rights. In particular, para. 252 of the Report holds that "effective implementation of

${ }^{44}$ Report of the United Nations Conference on Environment and Development. Rio de Janeiro, 3-14 June 1992 V. I: Resolutions adopted at the Conference (A/CONF.151/26/Rev.1(Vol.1)), UN, New-York, 1993, p. 11 [in Russian].

${ }^{45}$ Human Rights and the Environment. Final Report prepared by Special Rapporteur Mrs Fatma Zohra Ksentini (E/CN.4/Sub.2/1994/9, Russian) of 6 July 1994. UN Economic and Social Council. Commission on Human Rights. The Sub-Commission on the Prevention of Discrimination and Protection of Minorities. Session 46. Para. 4 of Preliminary agenda, 121 p. at: https://digitallibrary.un.org/record/226681/files/E_CN.4_ Sub.2_1994_9-RU.pdf?version=1 [in Russian]. 
the right to a satisfactory environment cannot be dissociated from the twinned efforts to preserve the environment and ensure the right to development. Nor can it be achieved without resolute action to ensure the enjoyment of all human rights" 46 . As can be judged by the text of the Report, the content of the human right to a healthy environment consists of the environmental aspects of the said fundamental human rights. Besides, as para. 255 of the Report runs, a specific feature of the right to a healthy environment is its preventive nature: "the right to a satisfactory environment is also a right to prevention which gives a new dimension to the right to information, education and participation in decision-making. The right to restitution, indemnification, compensation and rehabilitation for victims must also be seen from the angle of the special responsibility that would follow from the absence of preventive measures" ${ }^{\text {"47 }}$.

Annex I to Ksentini Report presents "Draft Principles on Human Rights and the Environment" ${ }^{\text {. }}$. The draft Declaration consists of Preamble and 27 paragraphs divided into 5 parts. In effect, this is the first draft instrument on environmental human rights submitted for consideration at such a high official international level. Keeping in mind the structure of the Draft and the order of presentation of normative materials, it is obvious that the right to a secure, healthy, ecologically sound environment formalized in para. 2 Part I, according to Special Rapporteur, is fundamental and hierarchically overarching in the system of individual environmental rights. All other rights are devoted to separate aspects of its realization: the right to freedom from pollution, environmental degradation and activities that adversely affect the environment, threaten life, health, livelihood, well-being or sustainable development within, across or outside national boundaries (para. 5); the right to protection and preservation of the air, soil, water, sea-ice, flora and fauna, and the essential processes and areas necessary to maintain biological diversity and ecosystems (para. 6); the right to the highest attainable standard of health free from environmental harm (para. 7); the right to safe and healthy food and water adequate to their well-being (para. 8); the right to a safe and healthy working environment (para. 9); the right to adequate housing, land tenure and living conditions in a secure, healthy and ecologically sound environment (para. 10) etc ${ }^{49}$.

\footnotetext{
${ }^{46}$ Id., at p. 93.

${ }^{47}$ Id., at p. 94 .

${ }^{48}$ Id., at pp. $98-102$.

${ }^{49}$ Id., at p. 99.
} 
A new stage in enshrining in international law of conceptions of sustainable development and human environmental rights was marked by the Johannesburg Declaration on Sustainable Development, adopted at the World Summit on Sustainable Development in Johannesburg, 26 August 4 September 2002. In the context of the present paper, the Declaration is of particular interest in that it specifies basic human needs which, in the view of its drafters, ensure 'indivisibility of human dignity'. The literal formulation is given in para. 18: "We welcome the focus of the Johannesburg Summit on the indivisibility of human dignity and are resolved, through decisions on targets, timetables and partnerships, to speedily increase access to such basic requirements as clean water, sanitation, adequate shelter, energy, health care, food security and the protection of biodiversity."

To our mind, this provision of the Declaration, although not formulated as a self-executing norm, nevertheless gives a clue to understanding the content of 'a favorable environment' concept. In this case, it demonstrates a universal political consensus which allows disagreeing with the opinions existing in the doctrine on general lack of interpreting the notion of 'favorable' or any standards thereof in the modern international law ${ }^{50}$.

As it follows from para. 18 cited above, an environment is 'favorable' when living in it permits people to preserve their dignity, as their basic needs are satisfied, in particular: the needs for pure water, sanitation, adequate housing, energy, healthcare, food safety and protection of biological diversity.

The hopes of environmentalists, related to the UN Conference on Sustainable Development in Rio de Janeiro (Rio+20), held on 20-22 June 2012 (at the twentieth jubilee of adoption of the Rio de Janeiro Declaration on Environment and Development 1992), alas, have not been fulfilled. For the most part, two topics were discussed: a) creation of 'green economy' to achieve sustainable development and poverty eradication; and b) improvement of international coordination of sustainable development ${ }^{51}$. Neither a research of the Office of the UN High Commissioner for Human Rights on the relationship between

\footnotetext{
${ }^{50}$ A.M. Solntsev, supra at pp. 25-27 [in Russian].

${ }^{51}$ The Outcome Document of the United Nations Conference on Sustainable Development in Rio de Janeiro (20-22 June 2012): Draft Resolution submitted by President of the General Assembly, "The future we want" (A/66/L.56, Russian), 24 July 2012, at: https://documents-dds-ny.un.org/doc/UNDOC/LTD/N12/436/90/PDF/N1243690.pdf? OpenElement [in Russian].
} 
climate change and human rights, conducted before RIO $+20^{52}$, nor persistent open calls of the High Commissioner Navi Pillay herself to the Conference member states to use her for the development of international environmental human rights were taken into consideration ${ }^{53}$.

\subsection{Current activity of the UN Human Rights Council on development of the content of the human right to a favorable environment (2012 till present)}

Immediately after the Conference, the Office of the UN High Commissioner for Human Rights and the UN Human Rights Council boosted their work on development of the international environmental protection agenda. The Council sessions started hearing annual reports made, first by the Independent Expert, and later on - since enhancement of his status in 2016 - by the Special Rapporteur on the issue of human rights obligations relating to the enjoyment of a safe, clean, healthy and sustainable environment John H. Knox ${ }^{54}$. Based on them, from 2012 to

${ }^{52}$ Report of the Office of the United Nations High Commissioner for Human Rights on the Relationship between Climate Change and Human Rights of 15 January 2009 (A/HRC/10/61, Russian), at: https://documents-dds-ny.un.org/doc/UNDOC/GEN/G09/103/ 46/PDF/G0910346.pdf? OpenElement; Analytical study of Relationship between Human Rights and the environment. Report of the United Nations High Commissioner for Human Rights of 16 December 2011 (A/HRC/19/34, Russian), at: http://www.ohchr.org/ Documents/HRBodies/HRCouncil/RegularSession/Session19/A-HRC-19-34_ru.pdf [in Russian].

${ }^{53}$ Open Letter from the United Nations High Commissioner for Human Rights Navi Pillay to Member States of the UN Conference on Sustainable Development in Rio de Janeiro (Brazil, 20-22 June 2012) of 30 March 2012, at: http://www.ohchr.org/Documents/ Issues/Development/OpenLetterHC.pdf; Statement by the United Nations High Commissioner for Human Rights: Navi Pillay calls on the member states to include human rights into Rio+20, 18 April 2012, at: http://www.ohchr.org/RU/NewsEvents /Rio20/Pages/ Newsreleases.aspx; Goal: Human Rights in Rio, 2 May 2012, at: http://www.ohchr.org/ RU/NewsEvents/Stories /Pages/WantedHumanRightsinRio.aspx [in Russian].

${ }^{54}$ Report of the Independent Expert on the issue of human rights obligations relating to the enjoyment of safe, clean, healthy and sustainable environment John H. Knox. Preliminary report of 24 December 2012 (A/HRC/22/43, Russian) / Human Rights Council. Session 22, at: https://documents-dds-ny.un.org/doc/UNDOC/GEN/G12/189/74/PDF/ G1218974.pdf?OpenElement [in Russian]; Report of the Independent Expert on the issue of human rights obligations relating to the enjoyment of safe, clean, healthy and sustainable environment John H. Knox. Analytical report of 30 December 2013 (A/HRC/25/53, Russian) / Human Rights Council. Session 25, at: http://www.ohchr.org/EN/HRBodies/ HRC/RegularSessions/Session25/Documents/A-HRC-25-53_ru.doc [in Russian]; Report of the Independent Expert on the issue of human rights obligations relating to the enjoyment of safe, clean, healthy and sustainable environment, John H. Knox, Compilation of good 
2017 the Council adopted a number of resolutions ensuring the development of international environmental human rights obligations and their fulfillment. For that purpose, two main areas were designated: a) general international legal obligations relating to the enjoyment of a safe, clean, healthy and sustainable environment ${ }^{55}$, and b) obligations, relating to climate change ${ }^{56}$.

practices, 3 February 2015 (A/HRC/28/61) / Human Rights Council. Session 28, at: http://www.ohchr.org/EN/HRBodies/HRC/RegularSessions/Session28/Documents/A_HRC _28_61_EN.doc [in Russian]; Report of the Independent Expert on the issue of human rights obligations relating to the enjoyment of safe, clean, healthy and sustainable environment, John H. Knox, 1 February 2016 (A/HRC/31/52, Russian) / Human Rights Council. Session 31, at: http://www.ohchr.org/EN/HRBodies/HRC/RegularSessions/ Session31/Documents/A\%20HRC\%2031\%2052_R.docx [in Russian]; Report of the Independent Expert on the issue of human rights obligations relating to the enjoyment of safe, clean, healthy and sustainable environment, 28 December 2015 (A/HRC/31/53, Russian) / Human Rights Council. Session 31, at: https://documents-dds-ny.un.org/doc/ UNDOC/GEN/G15/292/98/PDF/G1529298.pdf?OpenElement [in Russian]; Report of the Independent Expert on the issue of human rights obligations relating to the enjoyment of safe, clean, healthy and sustainable environment,19 January 2017 (A/HRC/34/49, Russian) / Human Rights Council. Session 34, at: https://documents-dds-ny.un.org/doc/UNDOC/ GEN/G17/010/01/PDF/G1701001.pdf?OpenElement [in Russian].

${ }^{55}$ Resolution of Human Rights Council 19/10 "Human Rights and the Environment" of 22 March 2012. General Assembly. Official reports. Session 67. Annex No 53 (A/67/53, Russian). Report of Human Rights Council. UN, New York, 2012, pp. 42-45, at: https://documents-dds-ny.un.org/doc/UNDOC/GEN/G12/161/19/PDF/G1216119.pdf?Open

Element [in Russian]; Resolution of Human Rights Council 25/21 "Human Rights and the Environment" of 28 March 2014. General Assembly. Official reports. Session 69. Annex No 53 (A/69/53, Russian). Report of Human Rights Council. UN, New York, 2014, pp. 101-104, at: https://documents-dds-ny.un.org/doc/UNDOC/GEN/G14/142/70/PDF/G1414270.pdf? OpenElement [in Russian]; Resolution of Human Rights Council 28/11 "Human Rights and the Environment" of 26 March 2015. General Assembly. Official reports. Session 70. Annex No 53 (A/70/53, Russian). Report of Human Rights Council. UN, New York, 2015, pp. 75-78, at: https://documents-dds-ny.un.org/doc/UNDOC/GEN/G15/205/32/PDF/ G1520532.pdf?OpenElement [in Russian]; Resolution of Human Rights Council 31/8 "Human Rights and the Environment" of 23 March 2016. General Assembly. Official reports. Session 71. Annex No 53 (A/71/53, Russian). Report of Human Rights Council. UN, New York, 2016, pp. 58-61, at: https://documents-dds-ny.un.org/doc/UNDOC/GEN/ G16/196/01/PDF/G1619601.pdf?OpenElement [in Russian]; Resolution of Human Rights Council 34/20 "Human Rights and the Environment" of 24 March 2017. General Assembly. Official reports. Session 72. Annex No 53 (A/72/53, Russian). Report of Human Rights Council. UN, New York, 2017, pp. 108-112, at: https://documents-dds-ny.un.org/doc/ UNDOC/GEN/G17/246/53/PDF/G1724653.pdf?OpenElement [in Russian].

${ }^{56}$ Resolution of Human Rights Council 26/27 "Human Rights and the Environment" of 27 June 2014. General Assembly. Official reports. Session 69. Annex No 53 (A/69/53, Russi“Human Rights and the Environment” of an). Report of Human Rights Council. UN, 
The Council resolution 34/20 "Human Rights and the Environment" of 24 March 2017 addressed the matter of mainstreaming the third environmental human rights area - preservation and sustainable use of biodiversity for well-being. In particular, the resolution indicates that "degradation and loss of biodiversity often result from and reinforce the existing patterns of discrimination, and that environmental harm can have disastrous, and at times geographically dispersed, consequences for the quality of life of indigenous peoples, local communities, peasants and others who rely directly on the products of forests, rivers, lakes, wetlands and oceans for their food, fuel and medicine, resulting in further inequality and marginalization"

Thus, the Council brought to a close the discussion on the purposefulness of individualization of international environmental human rights, and separated the human right to enjoinment of a safe, clean, and sustainable environment as being the key one. It stands to mention the wording of the norm. For the time being, it may be deemed to be final. It can be affirmed that it expresses a compromise reached at such a high international level after years-long scientific discussions and political coordination regarding the general name of the individual international environmental human rights norm, embodying the essence of the emerging international environmental human rights.

In the doctrine, there have always been problems as to working out a unified generally recognized formulation of this right, which reflects a lack of common understanding of its meaning and, consequently, its interpretation. Thus, B. Lewis noted that the forming right to a healthy

New York, 2014, pp. 243-247, at: https://documents-dds-ny.un.org/doc/UNDOC/ GEN/G14/142/70/PDF/G1414270.pdf? OpenElement [in Russian]; Resolution of Human Rights Council 29/15 "Human Rights and the Environment" of 26 March 2015. General Assembly. Official reports. Session 70. Annex No 53 (A/70/53, Russian). Report of Human Rights Council. UN, New York, 2015, pp. 231-233, at: https://documents-ddsny.un.org/doc/UNDOC/GEN/G15/205/32/PDF/G1520532.pdf?OpenElement [in Russian]; Resolution of Human Rights Council 32/33 "Human Rights and the Environment" of 1 July 2016. General Assembly. Official reports. Session 71. Annex No 53 (A/71/53, Russian). Report of Human Rights Council. UN, New York, 2016, pp. 334-339, at: https://documentsdds-ny.un.org/doc/UNDOC/GEN/G16/196/01/PDF/G1619601.pdf?OpenElement

[in Russian].

${ }^{57}$ Resolution of Human Rights Council 34/20 "Human Rights and the Environment" of 24 March 2017. General Assembly. Official reports. Session 72. Annex No 53 (A/72/53, Russian). Report of Human Rights Council. UN, New York, 2017, pp. 109, at: https://documents-ddsny.un.org/doc/UNDOC/GEN/G17/246/53/PDF/G1724653.pdf?OpenElement [in Russian]. 
environment has quite a broad range of equivalents: the 'right to a good environment', 'right to a clean, pure environment', 'right to a decent environment' etc. She wrote that, however, each formulation is open to interpretation, retaining the scope and content of the right in question unclear $^{58}$.

The same was mentioned by F.K. Nkusi who analyzed a number of international documents making use of the notions 'a satisfactory environment', 'a healthy and flourishing environment', 'a secure, healthy and ecologically sound environment', 'an environment of a quality that permits a life of dignity and well-being', etc. The scientist stated that insignificant international consensus as regards correct terminology affects negatively the formation of new rules in the sphere ${ }^{59}$.

L. Horn stressed that the lack of a correct definition of the human right to a healthy environment is one of the major obstacles on the way to the right development ${ }^{60}$. Additionally, she observed that the very term of 'environment' needs clarification - it can refer to the entire planet Earth or to man's immediate vicinities ${ }^{61}$.

The remarkable thing is that Special Rapporteur J. H. Knox in his first report to the Council also pointed out to a bulk of different formulations of this right that occur both in the universal international political documents and in regional international agreements, mostly adopted within the frameworks of the leading international regional organizations (the African Union, the League of Arab States, the Association of Southeast Asian Nations (ASEAN), the Council of Europe). He himself combined them within the formulation of the right to a healthy environment as the most recurrent in the documents ${ }^{62}$. In his further reports, the scientist preferred to use the notion of 'the right to enjoyment of a safe, clean, and sustainable environment'.

Apparently, the proposed formulation not only combined the right characteristics, most commonly used in the doctrine and practice, but also arranged in a certain value-based order the basic requirements to the

\footnotetext{
${ }^{58}$ Lewis B., supra at p. 40.

${ }^{59}$ Nkusi F.K., supra at p. 221.

${ }^{60}$ Horn L., supra at p. 239.

${ }^{61}$ Id., at p. 239.

${ }^{62}$ Report of the Independent Expert on the issue of human rights obligations relating to the enjoyment of safe, clean, healthy and sustainable environment John H. Knox. Preliminary report of 24 December 2012 (A/HRC/22/43, Russian). Human Rights Council. Session 22, pp. 6-8, at: https://documents-dds-ny.un.org/doc/UNDOC/GEN/G12/189/74/ PDF/G1218974.pdf?OpenElement [in Russian].
} 
quality of the environment. Firstly, it should be safe for man i.e. not to pose a threat to human existence in principle. Secondly, the criterion of 'cleanliness' definitely supplements the previous one, although it does not reduce 'safety' to a minimum standard, but rather lays increasingly tougher environmental claims to any kind of industrial enterprises or organizations. Thirdly, the criterion of a 'healthy' environment, being most popular in the modern constitutions and international documents, establishes a direct link with the human right to life, the theory and practice of which made it possible to formulate individual the most important attributes typical only of a human being as a living, self-existing organism, a unity of physical and spiritual, natural and social, inherited and acquired throughout life ${ }^{63}$. Health, pursuant to the preamble to Constitution of the World Health Organization is "a state of complete physical, mental and social well-being and not merely the absence of disease or infirmity" ${ }^{\prime 64}$. Therefore, a healthy environment is the external conditions of human life which ensure the state of complete physical, mental and social well-being.

Fourthly, the criterion of a 'sustainable environment indicates largescale and long-term prospects for this right evolution. It will be formed within the sustainable development concept - the main concept of the modern UN activity agenda. This means a commitment to toughening of social justice requirements in the matters of social organization and exploitation of natural resources, aiming to provide the capacity of the biosphere to cope with the effects of human activity ${ }^{65}$. In practical terms, this means a substantial provision of public international interests in realization of the individual right to enjoyment of a safe, clean, healthy and sustainable environment when meeting the relevant interests and needs of a given individual. What we mean is seeking the necessary balance between public and private interests by a number of international interstate human rights bodies in their handling claims of individuals and legal entities. The most illustrative example is the relevant practice of the European Court of Human Rights ${ }^{66}$.

${ }^{63}$ Miroshnychenko O.A., Human Right to Life (theory and practice of international cooperation). Extended abstract of candidate's thesis, 2005, p. 12 [in Ukrainian].

${ }^{64}$ Constitution of the World Health Organization, at: http://apps.who.int/gb/bd/PDF/ bd48/basic-documents-48th-edition-ru.pdf?ua=1\#page=9 [in Russian].

${ }^{65}$ Report to the UN General Assembly of the World Commission on Environment and Development "Our Common Future" of 4 August 1987 (Doc. A/42/427, Russian), p. 24, at: http://www.un.org/ru/ga/pdf/brundtland.pdf [in Russian].

${ }^{66}$ Kravchenko S. \& Bonine J. E., supra at pp. 245-287. 


\section{Objectification of the norm of the human right to a favorable environment in general international law}

The most active efforts of the UN Human Rights Council on international political and doctrinal consensus-building concerning the content of the norm of the human right to a favorable environment facilitate resolving the issue of its practical application, specifically - its formalization. In the world doctrine of international law, there is a prevailing opinion on impossibility of establishing the said norm in a universal international treaty even in the distant future.

It is evident that the present sources - for the most part international political documents - neither match the universal social value of the norm nor provide a solid ground for productive legal work on it. It is the level of "soft law' ${ }^{67}$. It is imperative to enhance the legal significance - "hardness" of a source. The leading experts in the field assert, to our mind not without reason, that such a "hard" source can be international legal custom. Its meaning as an effective regulator of international environmental relations is rarely denied. Particularly, in the Ukrainian science this line is taken by one of the leading experts in international environmental law M.O. Medvedieva. She writes that international custom is getting less and less suitable for regulating of environmental protection activity which, considering deterioration of environmental living standards, requires a clearer, more detailed and unambiguous legal regulation that can be provided only by treaty-based rules or further decisions of treaty bodies, in the least - by recommendations or 'soft law, ${ }^{68}$.

This position can hardly be accepted. Setting aside the general issues of the efficiency of international law of custom, it should be noted that in regard to the studied norm, at least in the western doctrine, its customlegal form is quite preferable. The discussions revolve mostly around the question whether the human right to a favorable environment has taken the shape of an international custom or not, and, one must note, neither position is prevailing here.

Not a few scientists believe that maintaining the existence of this custom is too early, although its creation process is certainly underway. In

${ }^{67}$ Weiss E.B., supra at p. 24; D.K. Anton \& D.L. Shelton, Environmental Protection and Human Rights. USA, NY: Cambridge University Press, 2011, pp. 63, 64.

${ }^{68}$ Medvedieva M.O., Specific features of creating international legal custom and treatybased rules in environmental protection. Bulletin of the Kiev National University named after T.G. Shevchenko: International relations, 2013, № 1 (40), p. 67; M.O. Medvedieva, Theoretical and practical aspects of realization of international legal norms in environmental protection, 2012, pp. 72-80. 
this connection, B. Lewis argues that, for one thing, it is still impossible to adequately outline the scope of this right, and, for another thing, there is no sufficient evidence of its opinio juris, i.e. recognition of its legally binding nature - a subjective element of a custom. Establishing the norm in international political documents and in multiple national constitutions is not enough. It should be enshrined in law and made a wide use of in the national courts ${ }^{69}$. B.H. Weston and D. Bollier, among the reasons impeding the recognition of 'a global international law right to environment', indicate: a) occurrence of this practice mainly in developing countries rather than in the advanced ones, and b) a trend of the African and Latin-American regional systems to protect the environmental rights of their native population ${ }^{70}$.

Of those who are positive as to sufficiency of evidence of the customary norm maturity, L. Horn takes a notable stand. Referring to numerous regional and national documents that reproduce the right to a favorable environment in one form or another, she asserts that in the past twenty years it has matured as an international legal custom ${ }^{71}$.

On the whole, sharing the views of supporters of the existence of international legal customary norm of the human right to a favorable environment, however, with due regard to the above criticism, we deem it necessary to make some clarifications.

Let us start with the scope of the norm. As discussed previously, thanks to the UN Human Rights Council it got its clear and correct wording - the right to enjoyment of a safe, clean and sustainable environment. Each of the words has its own subject matter which is evident both in terms of its ordinary meaning (as required by para. 1 Art. 31 of the Vienna Convention on the Law of Treaties, dated 1969), and from the perspective of its extensive interpretation with regard to practical needs. All the previous versions of this right wording contribute in a natural way the accumulated international and domestic experience of interpreting its various aspects. The norm has not appeared out of the blue. It has a background that fully conforms to a general idea of forming international legal customs. Actually, some scientists claimed as far back as in the early 1980s that there are reasons to acknowledge a broad

\footnotetext{
${ }^{69}$ Lewis B., supra at pp. 39-43.

${ }^{70}$ Weston B.H. \& Bollier D., supra at p. 15, at: http://commonslawproject.org/sites/ default/files/Regenerating\%20Essay\%2C\%20Part\%20I.pdf.

${ }^{71}$ Horn L., supra at p. 236.
} 
international recognition of this right, and notably in its shortest wording 'the right to the environment, ${ }^{72}$.

Needless to say that we agree with B. Lewis's point about the need for a wider implementation of the norm in the national law of as many states as possible, and in their court practice. However, a huge political and social consensus on it, laid down in multiple constitutional acts, is, to our mind, a valid evidence of the norm existence as an international legal custom. Additionally, J.H. Knox, Special Rapporteur of the UN Human Rights Council on this topic, states that, according to his estimates, constitutions of more than ninety (!) states establish directly the right to a healthy environment. He writes that this right is also included into regional human rights documents in Africa, Americas and in other places. Moreover, regional human rights courts apply universally recognized human rights, including the rights to life, health, and property, to consideration of environmental protection issues $^{73}$.

As for the scale of the practice, necessary for forming an international legal custom, we are fully supportive of the opinion D.K. Anton and D. Shelton in that the process of forming international legal customs in international environmental law is no different from the processes of custom formation in other international law areas. The practice, as the researchers rightly note, should not necessarily be universal in the sense that all the states on the globe must participate in $i t^{74}$. It is even less appropriate in this case to differentiate between the practice of advanced and developing states.

\section{CONCLUSIONS}

It can be said that the right to a favorable environment has already established itself as a norm of general customary international law. In spite of the scientific debates still in progress about its legal nature as a social origin of its binding power, an obvious consensus has been reached at the highest political level as regards a social significance of this right,

\footnotetext{
${ }^{72}$ Marks S.P., Emerging Human Rights: A New Generation for the 1980s? Rutgers Law Review, 1981, Vol. 33, pp. 442-444.

73 Knox J.H., Human Rights, Environmental Protection, and the Sustainable Development Goals, Washington International Law Journal, June 2015, Vol. 24, No. 3, pp. 519-520.

${ }^{74}$ Anton D.K. \& Shelton D. L., Environmental Protection and Human Rights, 2011, p. 62 .
} 
its close connections with other generally recognized human rights and freedoms of different generations that have developed universal and regional organizational and legal protection mechanisms.

Thanks to a number of international conferences held under UN auspices and an active position of the UN Human Rights Council, occupied by it since 2012, the norm has acquired a more elaborate wording that covers all the previous definitions of the right, specifically 'the right to enjoyment of a safe, clean, healthy and sustainable environment'. To our mind, this wording offers better opportunities for international and national practical activities on the legal protection of persons who suffered from violation of the right which it embodies.

Besides, this norm may entail unification of the relevant provisions contained in constitutions and regulatory acts of many states. In particular, it can also affect the norm set out in Art. 50 of the Constitution of Ukraine, providing for the human right to an environment that is safe for human life and health. Even though the sphere of relations that it regulates to a large extent corresponds to the sphere of relations regulated by international legal norm, it can be completed by targeted large-scale long-term prospects of preservation of the environment in the context of its sustainable development.

\section{SUMMARY}

The article explores the history of the development of content and formalization in today's general international law of the norm on the human right to a favorable environment. In the study of internationally known UN documents on the protection of the environment (Stockholm Declaration 1972, World Nature Charter 1982, Rio Declaration on Environment and Development 1992, Johannesburg Declaration 2002, etc.) and the analytical reports on this subject (Brundtland Report 1987, the report of Ksentini 1994, the reports of JH Knox presented to the UN Human Rights Council from 2012 to 2017), the authors of the article focused on the development of the process of individualization this right. Particular attention is paid to the analysis of documents adopted by the UN Human Rights Council from 2012 to the present. According to the authors, they allow, first, to give a more precise formulation of this right as the right to use a safe, clean, healthy and sustainable environment, and, secondly, to assert the formalization of this right as a universal international legal custom. 


\section{REFERENCES}

1. Weston B.H. \& Bollier D., supra at p. 15, at: http://commonslawproject.org/sites/default/files/Regenerating\%20Essay\% 2C\%20Part\%20I.pdf.

2. Lewis B., Environment Rights or A Right to the Environment? Exploring the Nexus between Human Rights and Environment Protection, Macquarie Journal of International and Comparative Environment Law, 2012, Vol. 8 (1), pp. 44-45.

3. Weiss B., The Evolution of International Environmental Law, Japanese Yearbook of International Law, 2011, p. 6.

4. Boyle A., Human Rights and the Environment: Where Next? European Journal of International Law, 2012, Vol. 23, P. 627.

5. Case of Kyrtatos v. Greece (Application No. 41666/98), Judgment, 22 May 2003.

6. Constitution of the World Health Organization, at: http://apps.who.int/gb/bd/PDF/bd48/basic-documents-48th-editionru.pdf?ua=1\#page=9 [in Russian].

7. García D.I. San José, Environment Protection and the European Convention on Human Rights, Council of Europe Publishing, 2005, pp. 7-11.

8. Anton D.K. \& Shelton D.L., Environmental Protection and Human Rights, 2011, p. 62.

9. Shelton D., Human Rights, Environmental Rights and the Right to Environment, Stanford Journal of International Law, 1991, Vol. 28, p. 111.

10.Weiss E.B., supra at p. 24; Anton D.K. \& Shelton D.L., Environmental Protection and Human Rights. USA, NY: Cambridge University Press, 2011, pp. 63-64.

11.Nkusi F.K., A Right to Healthy Environment: The Nexus between Environmental Protection and Human Rights, East African Journal of Science and Technology, 2015, Vol. 5, Issue 1, p. 222.

12. Gabčíkovo-Nagymaros Project (Hungary/Slovakia), Judgment of 25 September 1997, Separate Opinion of Vice-President Weeramantry, I.C.J. Reports, 1997, pp. 91-92.

13. Weston H. \& Bollier D., Regenerating the Human Right to a Clean and Healthy Environment in the Commons Renaissance. Essay, Version 1.0., September 2011, P. 74, at: http://commonslawproject.org/ sites/default/files/Regenerating\%20Essay\%2C\%20Part\%20I.pdf.

14. Human Rights and the Environment. Final Report prepared by Special Rapporteur Mrs Fatma Zohra Ksentini (E/CN.4/Sub.2/1994/9, 
Russian) of 6 July 1994. UN Economic and Social Council. Commission on Human Rights. The Sub-Commission on the Prevention of Discrimination and Protection of Minorities. Session 46. Para. 4 of Preliminary agenda, $121 \mathrm{p}$. at: https://digitallibrary.un.org/record/226681/ files/E_CN.4_Sub.2_1994_9-RU.pdf?version=1 [in Russian].

15. Knox J.H., Human Rights, Environmental Protection, and the Sustainable Development Goals, Washington International Law Journal, June 2015, Vol. 24, No. 3, pp. 519-520.

16. Horn L., The Implications of the Concept of Common Concern of a Human Kind on a Human Right to a Healthy Environment, Macquarie Journal of International and Comparative Environment Law, 2004, Vol. 1, p. 239.

17. Schwartz M.L., International Legal Protection for Victims of Environmental Abuse. Yale Journal of International Law, 1993, Vol. 18, Issue 1, Art. 15, p. 374.

18. Mushak N.B., Conceptual approaches to classification of human rights under globalization processes, Chasopys Kyivskoho universytetu prava, 2011, No 2, p. 300) [in Ukrainian].

19. Malanczuk P., Akehurst's Modern Introduction to International Law, 1997, p. 207-208; M. N. Shaw, International Law, 2008, pp. 533, 534.

20. Report of the Independent Expert on the issue of human rights obligations relating to the enjoyment of safe, clean, healthy and sustainable environment John H. Knox. Preliminary report of 24 December 2012 (A/HRC/22/43, Russian) / Human Rights Council. Session 22, at: https://documents-dds-ny.un.org/doc/UNDOC/GEN/G12/ 189/74/PDF/G1218974.pdf?OpenElement [in Russian]

21. Report of the Independent Expert on the issue of human rights obligations relating to the enjoyment of safe, clean, healthy and sustainable environment John H. Knox. Analytical report of 30 December 2013 (A/HRC/25/53, Russian) / Human Rights Council. Session 25, at: http://www.ohchr.org/EN/HRBodies/HRC/RegularSessions/Session25/Do cuments/A-HRC-25-53_ru.doc [in Russian]

22. Report of the Independent Expert on the issue of human rights obligations relating to the enjoyment of safe, clean, healthy and sustainable environment, John H. Knox, Compilation of good practices, 3 February 2015 (A/HRC/28/61) / Human Rights Council. Session 28, at: http://www.ohchr.org/EN/HRBodies/HRC/RegularSessions/Session28/Do cuments /A_HRC_28_61_EN.doc [in Russian] 
23. Report of the Independent Expert on the issue of human rights obligations relating to the enjoyment of safe, clean, healthy and sustainable environment, John H. Knox, 1 February 2016 (A/HRC/31/52, Russian) / Human Rights Council. Session 31, at: http://www.ohchr.org/ EN/HRBodies/HRC/RegularSessions/Session31/Documents/A\%20HRC\% 2031\%2052_R.docx [in Russian]

24. Report of the Independent Expert on the issue of human rights obligations relating to the enjoyment of safe, clean, healthy and sustainable environment, 28 December 2015 (A/HRC/31/53, Russian) / Human Rights Council. Session 31, at: https://documents-dds-ny.un.org/doc/UNDOC/GEN/ G15/292/98 /PDF/G1529298.pdf?OpenElement [in Russian]

25. Report of the Independent Expert on the issue of human rights obligations relating to the enjoyment of safe, clean, healthy and sustainable environment, 19 January 2017 (A/HRC/34/49, Russian) / Human Rights Council. Session 34, at: https://documents-ddsny.un.org/doc/UNDOC/GEN/G17/010/01/PDF/G1701001.pdf?OpenElem ent [in Russian].

26. Report of the Independent Expert on the issue of human rights obligations relating to the enjoyment of safe, clean, healthy and sustainable environment John H. Knox. Preliminary report of 24 December 2012 (A/HRC/22/43, Russian). Human Rights Council. Session 22, pp. 6-8, at: https://documents-dds-ny.un.org/doc/ UNDOC/GEN/G12/189/74/PDF/G1218974.pdf?OpenElement [in Russian].

27. Report of the Office of the United Nations High Commissioner for Human Rights on the Relationship between Climate Change and Human Rights of 15 January 2009 (A/HRC/10/61, Russian), at: https:// documents-dds-ny.un.org/doc/UNDOC/GEN/G09/103/46/PDF/G0910346. pdf? OpenElement; Analytical study of Relationship between Human Rights and the environment. Report of the United Nations High Commissioner for Human Rights of 16 December 2011 (A/HRC/19/34, Russian), at: http://www.ohchr.org/Documents/HRBodies/HRCouncil/RegularSession/ Session19/A-HRC-19-34_ru.pdf [in Russian].

28. Report of the United Nations Conference on Environment and Development. Rio de Janeiro, 3-14 June 1992 V. I: Resolutions adopted at the Conference (A/CONF.151/26/Rev.1(Vol.1)), UN, New-York, 1993, p. 11 [in Russian].

29. Report to the UN General Assembly of the World Commission on Environment and Development "Our Common Future" of 4 August 1987 
(Doc. A/42/427, Russian), 411 p., at: http://www.un.org/ru/ga/pdf/ brundtland.pdf [in Russian].

30. Resolution of Human Rights Council 19/10 "Human Rights and the Environment" of 22 March 2012. General Assembly. Official reports. Session 67. Annex No 53 (A/67/53, Russian). Report of Human Rights Council. UN, New York, 2012, pp. 42-45, at: https:// documents-dds-ny.un.org/doc/UNDOC/GEN/G12/161/19/PDF/G1216119. pdf?OpenElement [in Russian]

31. Resolution of Human Rights Council 25/21 "Human Rights and the Environment" of 28 March 2014. General Assembly. Official reports. Session 69. Annex No 53 (A/69/53, Russian). Report of Human Rights Council. UN, New York, 2014, pp. 101-104, at: https:// documents-dds-ny.un.org/doc/UNDOC/GEN/G14/142/70/PDF/G1414270. pdf?OpenElement [in Russian]

32. Resolution of Human Rights Council 26/27 "Human Rights and the Environment" of 27 June 2014. General Assembly. Official reports. Session 69. Annex No 53 (A/69/53, Russi"Human Rights and the Environment" of an). Report of Human Rights Council. UN, New York, 2014, pp. 243-247, at: https://documents-dds-ny.un.org/doc/UNDOC/ GEN/G14/142/70/PDF/G1414270.pdf? OpenElement [in Russian]

33. Resolution of Human Rights Council 28/11 "Human Rights and the Environment" of 26 March 2015. General Assembly. Official reports. Session 70. Annex No 53 (A/70/53, Russian). Report of Human Rights Council. UN, New York, 2015, pp. 75-78, at: https:// documents-dds-ny.un.org/doc/UNDOC/GEN/G16/196/01/PDF/G1619601. pdf?OpenElement [in Russian]

34. Resolution of Human Rights Council 31/8 "Human Rights and the Environment" of 23 March 2016. General Assembly. Official reports. Session 71. Annex No 53 (A/71/53, Russian). Report of Human Rights Council. UN, New York, 2016, pp. 58-61, at: https:// documents-dds-ny.un.org/doc/UNDOC/GEN/G16/196/01/PDF/G1619601. pdf?OpenElement [in Russian]

35. Resolution of Human Rights Council 32/33 "Human Rights and the Environment" of 1 July 2016. General Assembly. Official reports. Session 71. Annex No 53 (A/71/53, Russian). Report of Human Rights Council. UN, New York, 2016, pp. 334-339, at: https:// documents-dds-ny.un.org/doc/UNDOC/GEN/G16/196/01/PDF/G1619601. pdf?OpenElement [in Russian] 
36. Resolution of Human Rights Council 34/20 "Human Rights and the Environment" of 24 March 2017. General Assembly. Official reports. Session 72. Annex No 53 (A/72/53, Russian). Report of Human Rights Council. UN, New York, 2017, pp. 108-112, at: https:// documents-dds-ny.un.org/doc/UNDOC/GEN/G16/196/01/PDF/G1619601. pdf?OpenElement [in Russian]

37.Glazebrook S., Human Rights and the Environment. Victoria University of Wellington Law Review, 2009, Vol. 40, p. 317.

38. Kravchenko S. \& Bonine J.E., Interpretation of Human Rights for the Environment in the European Court of Human Rights, Global Business \& Development Law Journal, 2012, Vol. 25, p. 245-287.

39. Kravchenko S. \& Bonine J.E., supra at pp. 245-287.

40. Marks S.P., Emerging Human Rights: A New Generation for the 1980s? Rutgers Law Review, 1981, Vol. 33, pp. 442-444.

41.The Outcome Document of the United Nations Conference on Sustainable Development in Rio de Janeiro (20-22 June 2012): Draft Resolution submitted by President of the General Assembly, "The future we want" (A/66/L.56, Russian), 24 July 2012, at: https://documents-ddsny.un.org/doc/UNDOC/LTD/N12/436/90/PDF/N1243690.pdf?OpenElem ent [in Russian].

42. Universal Declaration of the Rights of Mother Earth, 28 April 2010 (Cochabamba, Bolivia), at: http://www.rightsofmotherearth.com/ универсальная-декларация-прав-матери-земли [in Russian].

43. Getman A.P. \& Kostytskyi V.V., Human environmental rights in the national and international legal doctrine, Problems of Legality, 2013, Issue 124, p. 78 [in Ukrainian].

44. Solntsev A.M., Protection of Environmental Human Rights, 2015, p. 25 [in Russian]

45.Kopylov M.N., Kopylov S.M. \& Mishlanov V.A., International Environmental Law is 175, Moscow Journal of International Law, 2014, № 1 (93), p. 104 [in Russian].

46. Medvedieva M.O., Specific features of creating international legal custom and treaty-based rules in environmental protection. Bulletin of the Kiev National University named after T.G. Shevchenko: International relations, 2013, № 1 (40), p. 67.

47. Medvedieva M.O., Theoretical and practical aspects of realization of international legal norms in environmental protection, 2012, pp. 72-80. 
48. Miroshnychenko O.A., Human Right to Life (theory and practice of international cooperation). Extended abstract of candidate's thesis, 2005, p. 12 [in Ukrainian].

49. Korotkiy T.R., Ecologization of international law in the light of environmental human rights, p. 134, at: http://archive.nbuv.gov.ua/portal/ Soc_Gum /App/2012_44/Korotkiy.pdf) [in Russian].

Information about the authors: Getman A. P., Doctor of Legal Sciences, Professor,

Vice-Rector for Scientific Work, Yaroslav Mudryi National Law University ORCID: 0000-0002-1987-2760

Shchokin Y. V., Doctor of Legal Sciences, Associate Professor of International Law Department, Yaroslav Mudryi National Law University ORCID: 0000-0002-8082-2367

Hetman Y. A., Doctor of Legal Sciences, Senior Research Fellow, National Academy of Legal Sciences of Ukraine ORCID: 0000-0002-1801-7252 